forum to defer to the foreign law only if that law is the sole and specific law applicable to the situation. 90

Professor Currie would agree, however, that application of the lex fori is not the most desirable solution to the problem if the disinterested state had some guide for determining which of the two states' statutes is to be applied, i.e., which of the two policies is to take precedence. To choose between the conflicting policies of two states is ultimately a decision which must be viewed as a legislative one. The choice is one appropriate for Congress, 91 not for a court. This is not to say that Congress should enact choice of law rules; it should simply decide which of two policies is to be dominant in a conflicts situation of this type-that which protects the deceased and his beneficiaries by granting extended damages, or that which protects the defendant by limiting the amount of recovery.

$90 \mathrm{Ibid}$. Professor Hill, however, concludes that application of the law of the forum would be unconstitutional. Hill, Governmental Interest and the Conflict of Laws $-A$ Reply to Professor Currie, 27 U. Chr. L. Rev. 463, 478 (1960).

91 See CoOK, The Logical and Legal Bases of the Conflict of Laws 90-107 (1949).

\title{
PROBATIONER'S RIGHT TO APPEAL; APPELLANT'S RIGHT TO PROBATION
}

Of the 26,808 criminal defendants convicted and sentenced in the United States district courts during the year ending June 30, 1958, 10,903 (41\%) were given suspended sentences and placed on probation. ${ }^{1}$ All of the states have some form of suspended sentence and probation or judicial parole procedure. 2 Despite the widespread use of probation, there has been surprisingly little discussion of its legal aspects. ${ }^{3}$ Perhaps because of this neglect, the "law" of probation has failed to provide uniform solutions to recurring legal problems. This comment will deal with three problem areas created

1 [1958] U.S. Admmistrative OfFice of the Unired States Courts, ANN. ReP. OF THE DIRECTOR 208-10, Table D-4 (1959). Annual reports for the years 1954-1957 show a similar incidence of the use of probation. Roughly 25,000 persons are under the supervision of United States probation officers at present. See id., p. 211, Table E-1.

2 Although the terms probation and parole are sometimes used interchangeably, they denote rather different institutions. For present purposes, the word "probation" will be used to designate extra-mural supervision of defendants convicted of crime, ordered by and subject to the control of the sentencing court. "Parole" is an "administrative act of the executive or an executive agency," and, unlike probation, typically follows a period of incarceration. 4 U.S. DEP'T OF JUSTICE, ATr'y GEN. SURVEY OF RELEASE Procedures 1 (1939).

${ }^{3}$ A recent exception may be found in Note, Legal Aspects of Probation Revocation, 59 Colum. L. Rev. 311 (1959). See GlueCK, Probation aNd Creminal Justice 23-46 (1933). The vast majority of the literature of probation, however, concerns itself with sociological and administrative problems. See, e.g., FEDERAL PROBATION, vols. 1-24 (19371960). 
by alleged conflicts between statutes providing for appellate review of criminal convictions and statutes providing for probation systems. These areas are: (1) review of the granting or denial of probation; (2) review of error in the trial when probation has been granted; and (3) the right to probation after affirmance on appeal. 4

In all jurisdictions probation is controlled by statutes which, in addition to establishing the probation machinery, empower the courts to utilize the machinery in appropriate cases. The statutory provisions are thus the proper point at which to begin any discussion of the law of probation.

All of the statutes provide that probation be granted or withheld at the discretion of the trial court. 5 With few exceptions, however, they limit the cases in which the power may be exercised. Commonly, persons convicted of particular crimes ${ }^{6}$ or of crimes carrying particular penalties 7 are not entitled to probation. Some statutes prohibit probation where the defendant has previously been convicted ${ }^{8}$ or incarcerated. ${ }^{9}$ Such restrictions upon the scope of probation reflect a legislative judgment as to the kinds of persons who should not excape incarceration. These statutes are based upon the assumption that this determination is more properly made by legislative exclusion of categories of defendants than by judicial consideration of

4 A related problem, appellate review of revocation proceedings, is adequately treated in Note, supra note 3 , at 333. The author there concluded that "where a hearing has been held, a probationer normally can appeal from a decision to revoke his probation ... but his chances of securing a reversal are considerably less than those of a defendant appealing from a criminal conviction."

5 The power may be made discretionary by specific provision that it be so; see, e.g., Fla. Stats. ANN. $\S \S 948.01-.09$ (Supp. 1960); GA. Code ANN. $\S \S 27-2702$ to -2723 (Supp. 1960); by granting the power (as opposed to the duty) of suspension and placement on probation: see, e.g., CoLO. REv. STATS. $\S \$ 39-16-1$ to -11 (1954); or merely by creating the power and providing that the court "may" use it. This latter is the most common method. See, e.g., IowA CODE ANN. $\$ \S 247.20-.27$ (1946); NEv. REv. STATS. $\$ \S 176.220-.350$ (1960); UTAH CODE ANN. §77-35-17 (1953).

6 E.g., D.C. CODE ANN. $\S \S 24-101$ to -105 (1951) (excluding defendants convicted of treason, homicide, rape, arson, kidnapping, or a second conviction of a felony); Orno REV. CODE $\$ \S 2951.02-.10$ (Baldwin 1960) (excluding defendants convicted of murder, arson, burglary of an inhabited dwelling house, incest, sodomy, rape without consent, assault with intent to rape and administering of poison). But see NEB. REv. STAT. \$\$29-2209 to -2220 (1956) (no limitation); ARIz. REv. STATS. $\$ \$ 13-1657,12-251$ to -253 (1956) (no limitation).

7 E.g., KY. REv. StatS. $\$ \S 439.260-.310$ (Supp. 1960) (excluding defendants convicted of crimes carrying penalty of life imprisonment or death); R.I. LAws ANN. \$§ 12-19-6 to -20 (1956) (excluding defendants convicted of offenses punishable by mandatory life imprisonment).

8 E.g., Miss. CoDE $\$ \S 4004.23-.5$ (1942) (probation not available where defendant previously convicted of felony); Mo. STATs. ANN. \$§549.060-190 (1949) (previous felony conviction disqualifies defendant for probation).

9 E.g., Mont. Rev. Code $\$ \S 94-7821$ to -7902 (Supp. 1959) (probation grantable if defendant has never before been imprisoned for crime). 
individual cases. The Standard Probation and Parole Act10 reflects the view, on the other hand, that no restrictions are necessary, save the good sense of the judge, and provision for reversal should he abuse his discretion.

If the defendant is eligible for probation, the statutes generally provide that an investigation and report concerning relevant aspects of the defendant's background may be made.11 On the basis of all the circumstances the court may, if "satisfied that the ends of justice and the best interest of the public as well as the defendant will be served thereby..."12 or that the defendant is not likely again to commit a crime, 13 suspend the imposition or execution of sentence and place the defendant on probation for a period within a prescribed maximum term ${ }^{14}$ on such conditions as the court deems suitable. ${ }^{15}$ Upon violation of any condition, the probationer may be re-arrested and brought before the court, which may continue, modify or revoke the order of probation. ${ }^{16}$ When probation is revoked, the court is usually empowered to execute the sentence imposed or, if imposition of sentence was suspended, to impose any sentence which might originally have been imposed.17 Upon successful completion of the probation period, the defendant is ordered discharged 18 and may, in a few states, 19 institute proceedings to expunge the conviction from the record. Against this background, and that provided by the statutes relating to appellate review, the problem areas noted above may be considered.

10 Nat'l Probation and Parole Ass'n, Standard Probation and Parole Act $\S 12$ (1955). [Hereinafter cited as Standard Act.] 1960).

11 E.g. ORE. REv., STATS. $\$ \$ 137.510-.630$ (1959); S.C. CODE $\$ \$ 55-591$ to -596 (Supp.

12 ALASKa COMP. LAWS ANN. $\$ \$ 66-16-31$ to -35 (Supp. 1957).

13 E.g., ARK. StaTs. ANN. $\$ \$ 43-2324$ to -2326 (Supp. 1959).

14 E.g., N.J. STATs. ANN. \$\$ 2A-168-1 to -17 (1953) (one-year minimum; five-year maximum); MinN. Stats. ANN. \$\$610.37-.39 (Supp. 1960) (term may not exceed length of suspended sentence); Mich. STATS. ANN. \$\$28.1131-.1144 (Supp. 1959) (non-felony: two-year maximum; felony: five-year maximum); Standard Act $\$ 16$ (not more than five years, subject to renewals for fixed periods not exceeding five years, but in no event to exceed the maximum term provided by law for the offense). But see MASs. ANN. LAws ch. 279, §§ 1-3 (1956) (probation for such time as court shall fix); IOWA CODE ANN. \$§ 247.20-.27 (1946) (for such period as court may set).

15 E.g., LA. StaTs. ANN. §§ 15.530-.538 (Supp. 1960); MD. ANN. CODE §§ 639-42 (1957).

16 E.g., Tenn. Code Ann. $\$ \S 40-2901$ to -2908 (1956); Tex. Code Crim. Proc. AnN. art. 781d (1957). As to the requirement of notice and a hearing in revocation proceeding see Annot., 132 A.L.R. 1248 (1941).

${ }^{17}$ E.g., Cal. Pen. Code $\$ \S 1203$ (a)-(c); Conn. Gen. Stat. $\$$ 54-103 to -116 (1958); IND. StAT. ANN. \$\$ 9-2209 to -2214 (1956).

18 E.g., PA. Stat. ANN. tit. 19, §§ 1051-85 (1930); W. VA. CoDe $\$ \S 6291.8-.22$ (Cum. Supp. 1960).

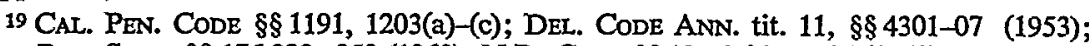
Nev. Rev. StaT. $\$ \S 176.220-.350$ (1960); N.D. CODE $\$ \S 12-53-01$ to -16 (1960); TEX. CoDE CRIM. Proc. art. 781(d) (1957); UtAH CODE ANN. \$77-35.17 (1953); WASH. Rev. CODE $\S \S 9.95 .200-.270(1960)$. 
The proper functioning of the probation system depends upon the wise exercise of the discretionary power lodged in the trial court. It would serve no useful end to substitute the discretion of an appellate court. It is not surprising, therefore, to find that probation determinations are reviewable only for abuse of discretion, or where the trial court has erroneously refused to hear and consider the appellant's application. The strength of this proposition is illustrated by the following excerpt from United States v. Wiley: "While we are strongly of the opinion that, if we were sitting in this case in place of the district judge, we would have granted Wiley's probation, we are not convinced that his taking an opposite view shows that he abused his discretion."'20

Although the question of review of a conviction after the granting of probation is analytically separable from that of the opportunity for probation after affirmance of a conviction on appeal, the impact of the rule in each situation is felt only in relation to the other. If these rules provide for both review and probation in appropriate cases, the order in which they must be sought is not of great significance. It is significant, however, when the rules provide for one procedure, only at the exclusion of the other. When this is the state of the law, defendants are confronted with a difficult choice; trial judges are able to prohibit appeals otherwise appropriate; and appellate courts can deprive trial courts of their discretionary powers.

It has been asserted that "as a general rule, the voluntary acceptance of a suspended sentence, probation or parole waives the defendant's right to appeal." 21 The cases demonstrate that, in addition to waiver, a probationer may be deprived of his right to appeal on a theory of estoppel or because the order granting probation is not a "final order." Even if one examines the leading cases decided under all of these theories, however, nothing approaching a "general rule" appears.

In Brooks v. State22 the imposition of sentence on a conviction of grand

20278 F.2d 500, 502 (7th Cir. 1960). In State v. Sibert, 6 Utah 2d 198, 310 P.2d 388 (1957), the Utah Supreme Court refrained from disturbing a denial of probation on appeal, explaining that "the granting or withholding of probation involves considering intangibles of character, personality and attitude, of which the cold record gives little inkling. ... [T] he problem of probation must of necessity rest within the discretion of the judge who hears the case." This, however, was not to say that a denial could not be "so capricious andarbitrary as to warrant the conclusion that he [the trial judge] did not in fact exercise his discretion" thereby justifying a review of his action. 6 Utah $2 \mathrm{~d}$ at $205,310 \mathrm{P} .2 \mathrm{~d}$ at 393 .

Accord, Baker v. State, 151 Tex. Crim. 454, 209 S.W.2d 769 (1948); Skelton v. State, 148 Neb. 30, 26 N.W.2d 378 (1947); People v. Racine, 362 III. 602, 1 N.E.2d 63 (1936); Thompson v. People, 136 Colo. 336, 316 P.2d 1043 (1957); People v. Rickson, 112 Cal. App. 2d 475, 246 P.2d 700 (1952). But see CAL. PEN. CoDE $\$ \$ 1237,1466$, expressly making an order granting or denying probation appealable.

21 Annot., 177 A.L.R. 929 (1938). For present purposes suspension of sentence and probation will be treated as two aspects of one procedure; parole will be considered only analogically.

2251 Ariz. 545, 78 P.2d 498, 117 A.L.R. 925 (1938). 
larceny was postponed and the defendant placed on probation. Two years later probation was revoked for violation of a condition, and final judgment of conviction and sentence were rendered. Defendant appealed, alleging error in the trial on the charge of grand larceny. To warrant dismissal of the appeal, the court need only to have held, as it did, that defendant's failure to prosecute an appeal until two years after trial operated to waive that right. In justification the court referred to the difficulty of obtaining a transcript of the proceedings and of producing evidence if the case were reversed and remanded. But the court went on: "By choosing probation he [defendant] is automatically estopped from appealing and by deciding in favor of appeal he estops himself from benefiting from suspension." 23

Where the defendant has in fact entered upon a course of conduct consistent with the acceptance of the terms and conditions of probation by failing promptly to appeal therefrom, he may properly be held to have impliedly waived his right to review of the judgment.24 It is of course true that an express waiver of error may properly be enforced against the defendant. ${ }^{25}$ Where, however, the defendant has not waived appeal by word or deed, but has merely applied for, or allowed to be entered, an order of probation, no doctrine of waiver or estoppel should be applied. Thus, in State v. Goddard,26 the Oregon Supreme Court denied the state's motion to dismiss on the ground that by accepting probation, defendant had had waived his right of appeal. The court

2351 Ariz. at 551, 78 P.2d at 501. The last half of this statement, at least, is pure dictum. The court's reliance upon "estoppel” derives from Barnes v. State, 20 Ariz. 183, 178 Pac. 780 (1919). In Barnes, the defendant was convicted of the willful abandonment of his wife. The record showed that after denial of defendant's motion for a new trial, Barnes "did appear... and offer to enter into" an undertaking to furnish bond conditioned upon payment of specified sums for the support and maintenance of his wife "in consideration that the court should suspend sentence in said cause." 20 Ariz. at 185,178 Pac. at 780 . The bond was given and sentence was suspended. One week later defendant gave notice of appeal. The supreme court dismissed on the grounds that defendant's "actions... involved a waiver of his right of appeal;" and that since the "defendant asked for and received benefits from the order suspending proceedings against him ..." he was estopped "by his conduct inconsistent with an appeal, from prosecuting an appeal in this court...." 20 Ariz. at 187-88, $178 \mathrm{Pac}$. at 781-82. If the court was not using the terms "wavier" and "estoppel" as synonyms, the former would seem to be the less objectionable basis for the decision. To find the estoppel would ordinarily require some showing of reliance on the part of either the court or the wife; the opinion speaks only of "benefit" to the defendant. While the court's finding of an implied waiver in Brooks seems reasonable, the prompt prosecution of the appeal makes unwarranted a similar implication in Barnes.

24 State v. Miller, 225 N.C. 213, 34 S.E.2d 143 (1945) (appeal attempted four years after suspension); see State v. Griffin, 246 N.C. 680, 100 S.E.2d 49 (1957); Gossett v. State, 162 Tex. Crim. 52, 282 S.W.2d 59 (1955). Each of these cases recognizes the defendant's right to appeal, had it been exercised before "acceptance" by conduct of the terms and conditions of probation. Cf. Sutton v. State, 194 Ind. 479, 143 N.E. 353 (1924) (right of appeal held to have expired).

25 Renado v. Lummus, 205 Mass. 155, 91 N.E. 144 (1910). Cf. State v. Sawyer, 43 Minn. 202, 45 N.W. 155 (1890).

2669 Ore. 73, 133 Pac. 90 (1913). 
said: "Beyond the fact that the defendant has not attempted to break into the penitentiary $v i$ et armis, there is nothing to indicate that he has accepted the parole." 27 The court properly considered the conditions of probation as a "serious abridgement of the liberty of the citizen ...," concluding that "until it is shown that he has accepted them affirmatively, we think he should not be held to have waived his right of appeal."'28

In State v. Miller, 29 the North Carolina Supreme Court held that defendant's four-year acceptance of the terms and conditions of probation operated to waive "his right to appeal on the principle issue of his guilt or innocence. ..."30 Four years later, in State $v$. Barnhardt, 31 the court, purporting to follow the Miller precedent, flatly held that the mere acquiescence of the defendant in an order of probation operated to waive his right to appeal, even though appeal was attempted promptly. The Barnhardt rule was overruled sub silentio in 1955 by State v. Ritchie 32 and State v. Ingram. ${ }^{33}$ Whereas Barnhardt had held that the prompt appeal from a conviction where sentence was suspended was ineffective, since appellant had "abandoned" and waived his right to appeal, Ritchie and Ingram held that where a defendant appeals immediately following entry of suspended sentence, he negates his consent to the suspension. Such consent being necessary to the exercise of the trial court's suspending power, the cases were remanded for a "proper judgment" 34 after affirmance on the merits. This rule was followed in later cases. ${ }^{35}$

The legislature came to the court's rescue in 1959 by enacting a statute which permits a defendant to accept the terms upon which his sentence was suspended after affirmance on appeal. ${ }^{36}$ The defendant may still be held to have waived his right to review if by his conduct he "affirmatively consents" to the suspension, but a prompt appeal will no longer deprive him of his right to probation.

Since the demise of the Barnhardt rule, first implicitly by decision, then explicitly by statute, there is no longer any authority for the proposition that a defendant waives his right to appeal by the acceptance, without more, of

2769 Ore. at 77,133 Pac. at 91.

2869 Ore. at 77, 133 Pac. at 92. Accord, State v. Witte, 13 N.J. 598, 100 A.2d 74 (1953); Dorsett v. State, 162 Tex. Crim. 512, 287 S.W.2d 655 (1956). Cf. State v. Carpenter, 67 Idaho 277, 176 P.2d 919 (1947).

29225 N.C. 213, 34 S.E.2d 143 (1945). See note 28 supra.

30225 N.C. at 215,34 S.E. $2 d$ at 145.

31230 N.C. 223,52 S.E.2d 904 (1949).

32243 N.C. 183,90 S.E.2d 301 (1955).

33243 N.C. 190,90 S.E.2d 304 (1955).

${ }^{34}$ A "proper judgment" in these circumstances is apparently one which is not suspended. 35 State v. Miller, 246 N.C. 608, 99 S.E.2d 795 (1957); State v. St. Clair, 246 N.C. 183,97 S.E.2d 840 (1957).

36 N.C. GeN. STAT. $\$ 15-180.1$ (Cum. Supp. 1959). The statute recites that "the purpose of this section is to provide that by giving notice of appeal the defendant does not waive his acceptance of the terms of suspension of sentence." 
suspension of sentence and probation, although he may be required, to paraphrase Mr. Justice Holmes, to "turn square corners when dealing with the courts." It remains to be considered whether the right to review can be withdrawn by other means.

Again, the discussion commences with a purported "general rule": that "where there is a 'suspended sentence' there is no judgment, or no final judgment, from which an appeal or writ of error will lie." 37 In re Phillips 38 is typical of the decisions in which this rule has been applied. There the California Supreme Court held that where a trial court suspends the execution of sentence, the judgment is appealable and becomes final on affirmance. But where the courts suspends the imposition of sentence, there is no appealable judgment. 39

In all of the jurisdictions following the final order rationale, 40 the rule barring appeal is a judicial resolution of an apparent conflict between statutes empowering trial courts to grant probation and those empowering appellate courts to hear appeals. It is neither an obvious nor a necessary conflict. By authorizing both procedures without this restriction, it cannot be said that the legislatures intended them to be mutually exclusive. As a matter of statutory construction, one would expect the courts to give effect to both procedures, absent a jarring conflict.

The distinction between cases in which the imposition of sentence is suspended, and those in which sentence is imposed but execution suspended, 41 is evidently artificial. With regard to this distinction the United States Supreme Court has said: "the difference to the probationer between imposition of sentence followed by probation... and suspension of the imposition of sentence... is one of trifling degree." 42 The difference should be of even less concern to appellate judges. Whether the requirement of finality is met should not turn upon mere phraseology. The legal effect is the same in either case. Either order "terminates the litigation on the merits." 43 Either order is capable of "ultimately constituting a conclusive adjudication of the defendant's guilt." 44 Either order imposes punishment 45 upon the defendant,

37 Annot., 126 A.L.R. 1210 (1940).

3817 Cal. 2d 55, 109 P.2d 344 (1941).

${ }^{39}$ Accord, People v. Patello, 125 Cal. App. 480, 13 P.2d 1068 (1932); State v. Farmer, 39 Wash. 2d 675, 237 P.2d 734 (1951); State v. Sharp, 138 La. 656, 70 So. 573 (1916. Cf. State v. Vaughan, 71 Conn. 475, 42 Atl. 640 (1899) (stay until further order); Ingram v. State, 62 Okla. Crim. 344, 71 P.2d 646 (1937) (parole).

40 See note 39 supra.

41 In re Phillips, 17 Cal. 2d 55, 109 P.2d 344 (1941); State v. Farmer, 39 Wash. 2d 675, 237 P.2d 734 (1951). But see State v. Liliopoulos, 165 Wash. 197, 5 P.2d 319 (1931).

42 Korematsu v. United States, 319 U.S. 432, 435 (1943).

$43 \mathrm{Id}$. at 435.

44 Commonwealth v. Elias, 394 Pa. 639, 641, 149 A.2d 53, 54 (1959).

45 See 319 U.S. at 434-35. 
conditioning his continued freedom upon compliance with terms the court is without power to set absent a valid and proper conviction. 46 The fact that the punishment is milder than incarceration is, or ought to be, irrelevant: "[W] hat [the] defendant is seeking on ... appeal is not clemency but vindication." 47 For these reasons, many courts refuse to distinguish between suspended imposition and suspended execution of sentence, allowing an otherwise proper appeal in either case. 48

The Illinois probation statute provides that when a defendant's application for release on probation is granted, "the judge... shall thereupon enter an order continuing the cause" during the probation period. "A cause continued pursuant to the provisions of ... [the] Act ... [is] deemed subject to the jurisdiction of the court in which it is pending... for the full period of its continuance."49 It was on this "jurisdictional" provision that the Mlinois Supreme Court rested its decision in the only case in which that court dealt squarely with the question of a probationer's right to appeal. In People v. Mayfield, ${ }^{50}$ the defendant sought review by writ of error from a conviction of statutory rape. Prior to seeking review defendant had applied for and was granted release on probation. In view of this the court concluded that it was "without authority to review any phase of [the] ... case while jurisdiction is retained by the criminal court." 51

The Tennessee probation act provides that "the power of suspension and/or parole hereby granted to the trial judges shall not be exercised unless ... defendants making application [therefor] ... shall first either secure or pay all of the costs accrued at the instance of the state." 52 The Tennessee Supreme Court has held that "this language necessarily means that the power

46 The National Probation and Parole Association suggests the following as conditions of probation: "That the defendant shall (a) avoid injurious or vicious habits; (b) avoid persons or places of disreputable or harmful character; (c) report to the probation officer as directed; (d) permit the probation officer to visit him at home or elsewhere; (e) work faithfully at suitable employment as far as possible; (f) remain within a specified area; (g) pay a fine or costs ... ; (h) make reparation or restitution to the aggrieved party. . . ; (i) support his dependents." Standard Act $\$ 14$.

47 Thomas v. United States, 129 A.2d 852, 853 (D.C. Munic. Ct. App. 1957).

48 Korematsu v. United States, 319 U.S. 432 (1943); Blohm v. District of Columbia, 113 A.2d 111 (D.C. Munic. Ct. App. 1955); Commonwealth v. Elias, 394 Pa. 639, 149 A.2d 53 (1959). Cf. Glickman v. State, 190 Md. 516, 60 A.2d 216 (1948).

49 ILL. Rev. Stat. ch. 38, § 786 (Supp. 1960).

50414 III. 146, 111 N.E.2d 164 (1953).

51414 Ill. at 148, 111 N.E.2d at 165 . The appellate courts had previously (People v. Collis, 344 IIl. App. 539, 101 N.E.2d 739 (1951)) and have since (People v. Dowd, 27 Ill. App. 2d 429, 170 N.E.2d $179(1960)$ ) held that the defendant was barred from appeal on grounds of waiver and estoppel.

52 Tenn. Code AnN. \$ 40-2901 (1956). 
of the Court to suspend the sentence is limited to those cases in which a defendant does not exercise the right of appeal. The payment of costs, a prerequisite of the Court's authority to suspend sentence, is an act inconsistent with the act of appealing." 53 The court construed defendants' appeals as rejecting the trial court's "offer" of suspension. In affirming the judgments, the court therefore ordered them "modified so as to eliminate that portion of said judgment purporting to suspend the ... sentence." 54

It seems clear that the fact of "jurisdiction" or the "payment of costs" should not be so construed as to bar a probationer's right of appeal. As noted above, the language of the provisions neither requires nor suggests this interpretation. Probation systems are commonly instituted as adjuncts of the courts. The purpose of the Illinois jurisdiction provision is to grant "jurisdiction" to the probation department to be exercised under the supervision of the court. "Jurisdiction" for this purpose in no way affects the jurisdiction of the supreme court to entertain probationers' appeals. The Tennessee provision merely requires that those persons seeking clemency from the court first reimburse the state for the expense incurred in their behalf. In both Illinois and Tennessee the legislature has provided that defendants shall have a right to appeal from a conviction. 55 The very real conflict between these provisions and the decisions of the Illinois and Tennessee supreme courts barring a probationer's right to appeal far outweighs any alleged conflict on which those decisions were based.

Of the jurisdictions which have considered the right of a defendant to probation after affirmance on appeal, only three have denied it.56 In each case the lower court was held to be deprived of jurisdiction or power to grant probation by defendant's prosecution of an appeal. In no case is it suggested that unsuccessful appellants are in any way less deserving of probation than are persons who have not appealed, nor is any other justification offered. Again, the conflict between these rulings and the statutes authorizing probation would appear to be far more serious than the alleged conflict in jurisdiction averted by those rulings.

Although they are more numerous, it cannot be said that the decisions

53 Helton v. State, 195 Tenn. 491, 493, 260 S.W.2d 260, 261, (1953).

54195 Tenn. at 495, 260 S.W.2d at 262. Accord, Edgemon v. State, 195 Tenn. 496, 260 S.W.2d 262 (1953).

55 IIL. REV. STAT. ch. 38, $\$ 769.1$ (Supp. 1960) provides that "writs of error in all criminal cases are writs of right and shall be issued of course." TENN. CODE ANN. \$ 40-3401 (1956) provides that "either party to a criminal proceeding may ... pray an appeal in the nature of a writ of error to the Supreme Court as in civil cases."

56 Forbush v. Thatcher, 78 Idaho 597, 309 P.2d 203 (1957); Ex parte Foister, 203 Mo. 687, 102 S.W. 542 (1907); State ex rel. Zabel v. Municipal Court, 179 Wis. 195, 190 N.W. 121 (1922). Cf. State ex rel. Gentry v. Montgomery, 317 Mo. 811, 297 S.W. 30 (1927). 
allowing probation after affirmance shed any brighter light upon the problem. ${ }^{57}$ It is important, but not sufficient, to note that none of the states which deny probation after affirmance58 is among those which might arguably be said to deny appeal after probation. 59 This statement, however, is supported only by authority of a negative inference drawn from a strict interpretation of the cases. It can as easily be argued that all of these states would, in an appropriate case, find the procedures mutually exclusive. A broad, or superficial, reading of the cases which deny one procedure after the defendant has utilized the other may well be used to support this position.

\section{CoNCLUSION}

Where a party seeks review of the granting or denial of probation, it is generally allowed, although the issue-whether the trial court's discretion was abused-makes reversal a rare occurrence. The same may be said of review of revocation proceedings.60 Six jurisdictions may arguably be said to deny appeal when probation has been granted.61 Three jurisdictions bar probation after affirmance on appeal.62

As suggested above, there should not be serious criticism of a state policy which requires that a defendant seek probation or appeal in a particular order, even though the decisions so commanding offer no reasonable bases for the requirement. To require a choice, however, between probation and appeal is, it is submitted, unconstitutional under the equal protection clause of the fourteenth amendment. In Griffin v. Illinois ${ }^{63}$ the Supreme Court of the United States held that where a state provides for appellate review, the equal protection clause of the fourteenth amendment precludes the state from barring indigent defendants from appellate review simply because such defendants lack the means necessary to comply with the prescribed procedure. In Cochran v. Kansas ${ }^{64}$ and Dowd v. Cook ${ }^{65}$ the Court had found a deprivation of equal protection where prisoners incarcerated in state peniten-

57 See Gaston v. United States, 143 F.2d 10 (D.C. Cir. 1944) (dictum); Pernatto v. United States, 107 F.2d 372 (3d Cir. 1939); Ackerson v. United States, 15 F.2d 268 (2d Cir. 1926); Kriebel v. United States, 10 F.2d 762 (7th Cir. 1926); Nix v. James, 7 F.2d 590 (9th Cir. 1925); Ex parte Smith, 252 Ala. 415, 41 So. 2d 570 (1949); Lloyd v. Superior Court, 208 Cal. 622, 283 Pac. 931 (1929); State ex rel. Bottomly v. District Court, 73 Mont. 541, 237 Pac. 525 (1925); People ex rel. Woodin v. Ottaway, 247 N.Y. 493, 161 N.E. 157 (1928). $C f$. United States v. Murray, 275 U.S. 347 (1928).

58 Idaho, Missouri and Wisconsin. See note 57 supra.

59 Connecticut, Illinois, Louisiana, Oklahoma, Tennessee and Washington. See notes 39,50 and 53 supra.

60 Note, Legal Aspects of Probation Revocation, 59 Colum. L. Rev. 311, 333 (1951).

61 See note 59 supra.

62 See notes 58 and 56 supra.

64316 U.S. 255 (1942).

63351 U.S. 12 (1956).

65340 U.S. 206 (1951). 
tiaries were prevented from pursuing appeals from their convictions by prison rules prohibiting them from filing petitions in court.

By forcing a defendant to choose either probation or appeal, a state is in effect depriving probationers of the right to appeal. Unless there is an alternative procedure provided, as would be the case where probation was available after, but not before, appeal; or unless it can be said that it is reasonable to withdraw the right of appeal from probationers as a class, the procedure is open to constitutional attack.

In light of the Cochran and Dowd cases, a contrary ruling would give fewer rights to probationers than to prisoners. The argument that probationers, being persons whom the court had adjudged capable of rehabilitation, are therefore more worthy of protection than are prisoners will not be made. That would invite a distinction based upon the fact that since probationers are not incarcerated, they are not in need of such protection. These considerations are irrelevant. The indisputable fact is that to be placed on probation is to be punished. Defendants ought not to be discriminated against on the ground that they have received probation rather than incarceration any more than should defendants who have been fined rather than incarcerated. The only important differences between the situation under consideration and the facts of Griffin and Dowd appear to support the proposition put forward. In Griffin the state discriminated against indigent defendants; here it discriminates against defendants amenable to rehabilitation. In Griffin the state was not allowed to accept the "natural" distribution of wealth as a basis for classification; here it should not be allowed to accept the type of punishment (which the state itself provides) as a basis for classification. In Griffin and Dowd it was the action of executive officers that caused the discrimination; here it is the erstwhile protector of the defendants rights-the judiciary-which forces the choice. 66

As Mr. Justice Black said in Griffin, "Plainly the ability to pay costs ... bears no rational relationship to a defendant's guilt or innocence and could not be used as an excuse to deprive a defendant of a fair trial." 67 So here the punishment 68 imposed upon a convicted defendant bears no relationship to his guilt or innocence. Where a state chooses to deny the right of appeal to probationers, while granting it to all others, it may well violate the equal protection clause of the fourteenth amendment.

66 This statement assumes that there is no reasonable basis for the asserted conflict between the probation and the appeal statutes. If there were, the responsibility would fall only indirectly upon the judiciary-for applying an unconstitutional statute-and primarily upon the legislature and executive, but nonetheless upon the state.

67351 U.S. at 17-18.

${ }^{68}$ See note 46 supra. 